\title{
PROTESTANTISM AND EDUCATION: READING (THE BIBLE) AND OTHER SKILLS
}

\author{
TIMO BOPPART, JOSEF FALKINGER and VOLKER GROSSMANN*
}

\begin{abstract}
During industrialization, Protestants were more literate than Catholics. This paper investigates whether this fact may be led back to the intrinsic motivation of Protestants to read the bible and to what extent other education motives might have been involved as well. We employ a historical data set from Switzerland which allows us to differentiate between different cognitive skills: reading, numeracy, essay writing, and Swiss history. We develop an estimation strategy to examine whether the impact of religious denomination was particularly large with respect to reading capabilities. We find support for this hypothesis. However, we also find evidence which is consistent with the view that Protestants' education motives went beyond acquiring reading skills. (JEL I20)
\end{abstract}

\section{INTRODUCTION}

Recent research motivated by Weber (1905), who hypothesized that Protestants' work ethic is conducive to faster economic development, has delivered interesting novel insights. For instance, Becker and Woessmann (2009) argue that Protestant regions in late nineteenth-century Prussia grew faster than Catholic areas owing to higher literacy rates among Protestants. Becker and Woessmann (2010) provide evidence for preindustrialization Prussia (the year 1816) that both the density of primary schools and primary school enrollment were higher in Protestant

*We are grateful to Christian Dustmann, Guy Kirsch, Aderonke Osikominu, and two anonymous referees for valuable discussions. Moreover, we thank the participants at the annual meeting of the Verein für Socialpolitik 2011 in Frankfurt, Germany for helpful comments and suggestions. We are particularly indebted to Ulrich Woitek and Gabriela Wüthrich for providing us with the data and some historical background.

Boppart: Institute for International Economic Studies, Stockholm University, Stockholm 10405, Sweden; Department of Economics, University of Zurich, Zurich 8032, Switzerland. Phone +46 816 3552, Fax +46 8 16 1443, E-mail timo.boppart@iies.su.se

Falkinger: Department of Economics, University of Zurich, Zurich 8032, Switzerland; CESifo, Munich; Institute for the Study of Labor (IZA), Bonn, Germany. Phone +41 44634 2291, Fax +41 44634 4996, E-mail josef.falkinger@econ.uzh.ch

Grossmann: Department of Economics, University of Fribourg, Fribourg 1700, Switzerland; CESifo, Munich; Institute for the Study of Labor (IZA), Bonn, Germany. Phone +41 26300 9383, Fax +41 26300 9678, E-mail volker.grossmann@unifr.ch regions. ${ }^{1}$ In a similar vein, Boppart et al. (2013) show that, on average, Protestant regions in nineteenth-century Switzerland were associated with higher school expenditure and higher educational performance. ${ }^{2}$

This paper attempts to identify the educational motives of Protestants. ${ }^{3}$ Was there a particular emphasis of Protestants for reading capabilities, possibly to read the bible? Were Protestants also better skilled in other fields like mathematics, that is, had they been motivated to

1. This rules out that the emphasis on schools of Protestant regions was merely a response to higher demand for human capital during industrialization. Rather, it may have been a result of the reformation process itself, which in Germany had been led by Martin Luther. According to Painter $(1886,147)$ : "Though no complete system of popular instruction was established, the foundation for it was laid. To this great result Luther contributed more than any other man of his time; and this fact makes him the leading educational reformer of the sixteenth century."

2. In addition, they find an important interaction effect with other cultural attitudes. Religious denomination primarily mattered for educational performance in a conservative environment, characterized by referenda results on issues which could be associated with conservative values.

3. By focusing on education we do not deny, of course, that religion may shape economically relevant human behavior through many other channels, as discussed, for instance, in the survey by Iannaccone (1998).

\section{ABBREVIATIONS}

IV: Instrumental Variable

OLS: Ordinary Least Squares 